Landslides (2019) 16:2299-2300 DOI 10.1007/s10346-019-01302-8 Received: 12 September 2019 Accepted: 27 September 2019 Published online: 25 November 2019 (c) Springer-Verlag GmbH Germany part of Springer Nature 2019
Taikan 0ki

\section{Foreword by Prof. Taikan OKI of the United Nations University (UNU) for the Journal of the International Consortium on Landslides}

It is my great pleasure to give this foreword to the Journal of the International Consortium on Landslides. Representing the United Nations University (UNU), I have signed the Kyoto Landslide Commitment 2020. This commitment shows multi-stakeholder commitments towards the implementation of the global frameworks supporting sustainability, the 2030 Agenda for Sustainable Development, the Sendai Framework, Paris Climate Agreement, and the New Urban Agenda.

The role of UNU in supporting ICL/IPL activities

UNU has long supported ICL/IPL activities. It was first started by Prof. Hans van Ginkel, Rector of the United Nations University and United Nations Under-Secretary General. He was appointed Rector of the United Nations University in Tokyo in 1997-2007. Professor van Ginkel has actively contributed to the work of international organizations, notably UNESCO, as a member of the Special Advisory Group on Higher Education established by the Director General. The Tokyo Action Plan was adopted at the Tokyo Round Table Discussion Strengthening Research and Learning on Earth System Risk Analysis and Sustainable Disaster Management within UN-ISDR as Regards Landslides organized at the United Nations University in Tokyo from 18 to 20 January 2006. Prof. van Ginkel took major role to establish the 2006 Landslide Tokyo Action Plan. ICL further exchanged MoU with UNESCO, WMO, FAO, UNDRR (UNISDR), UNU, ISU (ICSU), and WFEO to promote IPL in 2006. Based on this MOU, the current International Programme on Landslides (IPL) and the Global Promotion Committee of the IPL has been established. UNU was also involved as the signatory organizations of Sendai Partnerships signed during the 2015 WCDR in Sendai, Japan, the event which marked the adoption of the Sendai Framework for Disaster Risk Reduction (SFDRR).

Another important figure, Prof. Jacob Rhyner, a former UNU Vice Rector in Europe, worked as the chair of the high-level panel discussion Strengthening Intergovernmental network and IPL for "SDR-ICL Sendai Partnerships 2015-2025 for global promotion of understanding and reducing landslide disaster risk on 30 May 2017 in the Fourth World Landslide Forum held in Ljubljana, Slovenia, which subsequently lead to the 2017 Ljubljana Declaration adoption. It included the plan of the Firth World Landslide Forum in 2020 and the idea of the Kyoto 2020 Commitment for Global Promotion of Understanding and Reducing Landslide Disaster Risk.

I joined the United Nations University as Senior Vice-Rector on 1 October 2016. My responsibilities include supporting management initiatives UNU-wide and maintaining UNU's scientific partnership with the University of Tokyo and broader relationships in Japan, including with government ministries and the public. I have been working as researcher on global hydrology and the sustainability of world water resources.

Landslide hazards, risks, disasters, and risk reduction are strongly related to global hydrology and the sustainability of world water resources. Landslide is one of the costliest geo-hazards and often the results of interactions between geo-hazards of tsunamis, earthquakes and volcanic eruptions, and water-related hazards of rainfall, floods, typhoons, or even droughts. Multi-hazards early warning systems that also incorporate potential landslide are hence important. The ability to assess the level of hazards, vulnerability, and risks is paramount, as is community-based and naturebased approaches to deal with landslide risks.

UNU has been working on issues related to landslide risk assessments, disaster risk reduction and its relations to broader sustainable agendas As a leading research and teaching institute globally, UNU has been making important contributions to advancing international policy agendas including the 2030 Agenda, the Sendai Framework for Disaster Risk Reduction (SFDRR), Paris Agreement on climate change and others include for example Convention on Biological Diversity, Global Education 2030 Agenda in particular the Global Action Program on Education for Sustainable Development.

UNU calls for coherence in the implementation of the SDGs, SFDRR, and Paris Agreement on climate change. To support the implementation for the SFDRR, UNU focus our research on social implications of disasters and the interlinkages between disaster risk reduction (DRR) and climate change adaptation (CCA). This for example through the interactions between social-ecological systems and resilience, by developing ecosystem-based DRR and CCA, which has great potential to support landslide risk reduction. Landslide risk reduction is strongly related to different SDGs. On SDG 11, cities are the area where land-based infrastructures and people are concentrated. Landslide may threaten the continuity of the process of the city. Moreover, low-income, poor, and informal urban inhabitants may have to occupy and live on high-risk areas including landslide-prone hills or flood-prone river banks. SDG 13 is related to Climate Action. Climate change is expected to increase the frequency, intensity, and complexity of disasters, which also include landslide disasters. A warming world leads to dry areas become drier and wet areas become wetter. Landslide early warning system and community disaster preparedness to landslide are approaches which DRR and CCA integration can take place. For SDG 15 is about life on land. Terrestrial forests play a central role in building and maintaining soil fertility, slowing land degradation, halting landslides particularly in mountainous areas, and protecting against disasters. Ecosystem-based disaster risk reduction should be in the heart of landslide risk reduction.

In terms of the 2030 Agenda for Sustainable Development, UNU-IAS focus on governance and institutional structures to support Member States in implementing effective multi-stakeholder partnerships. This also includes partnerships in DRR, as shown in our meeting today. In 2017, we formed a new partnership with the UN Economic and Social Commission for Asia and the Pacific (ESCAP) to advance 


\section{Preface}

implementation of the 2030 Agenda in the region and jointly developed guidelines for Member States to implement effective multi-stakeholder partnerships for the SDGs. Though the initiative continuing more than 20 years, we commit to raise local awareness of internationally important agenda by disseminating information and providing forum for dialogue. Through these activities, we aim to accelerate the progress towards new partnerships and achievements of internationally important targets through localization. The 17 goals of the SDGs contain crosscutting issues and disasters. The disaster risk arises when hazards interact with the environmental, social, and economic vulnerabilities. Thus, the ambitious targets set by both the SDGs and Sendai Framework can only be achieved through multi-stakeholder partnerships.

Congratulations once again to the ICL/IPL on having to approve the 2020 Kyoto Commitment. I wish ICL/IPL will pave ways for new partnerships with different stakeholders and I look forward for broader commitment to the achievement of the SDGs.

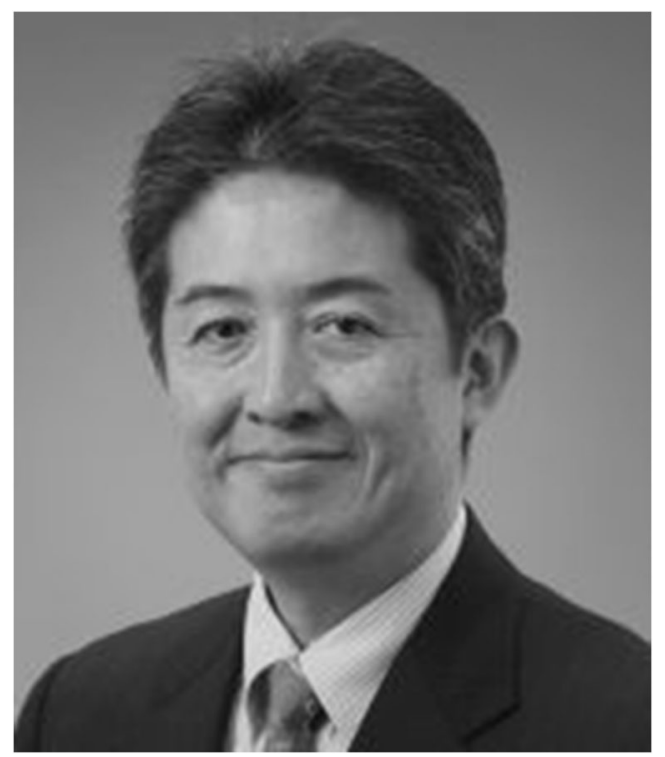

Professor Taikan Oki, Assistant Secretary General - United Nations, Senior Vice Rector - United Nations University 